\title{
Implementation Of Village Funds In Implementation Of Development As An Effort To Improve Community Welfare In Kadiwono Village, Bulu District, Rembang Regency
}

\begin{abstract}
Ahmad Ridwan ${ }^{1}$ and Widayati ${ }^{2}$
Abstract: One of the most important things in Act No. 6 of 2014 on Villages is the existence of special rules contained therein which contain regarding village funds. Research will answer the problem formulation that is how the implementation of village funds in the form of implementation of development in the Kadiwono Village, Bulu District, Rembang Regency. The method of approach in this research uses the sociological juridical method with the research specifications descriptively analysis. The data used for this study are primary and secondary data taken from field observation, interviews, and literature study methods. Based on the research concluded in 2019, Kadiwono Village, Bulu District, Rembang Regency obtained Village Revenues totaling Rp 1,500,432,113 consisting of village funds, tax revenue-sharing, retribution sharing, village fund allocation, provincial financial assistance, district financial assistance, and the remaining 2018 budget (SILPA). In village expenditure, Kadiwono Village divides 4 areas in village expenditure through the allocation of village funds, namely (1) the field of village governance, (2) development, (3) community development, (4) and community empowerment.

Keywords: Village Funds; Development; Public Welfare.
\end{abstract}

\section{Introduction}

The 1945 Constitution of the Republic of Indonesia as a reference for all policies of the regional government towards various regional development sectors including legal, economic, social and cultural policies. Based on Article 33 paragraph (4) of the 1945 Constitution of the Republic of Indonesia that "the national economy is organized based on economic democracy with the principles of togetherness, equitable efficiency, sustainable, environmentally friendly, independent, and by maintaining a balance of progress and national economic unity" and In Article 34 paragraph (2) of the 1945 Constitution of the Republic of Indonesia that "the State develops a social security system for all people and empowers people who are weak and unable to comply with human dignity".

The Village Act No. 6 of 2014 on Villages gives new hope to villagers. The law, which was signed directly by the former 6th President of Indonesia, namely Susilo Bambang Yudhoyono, made the village have an important role for regional autonomy, and the policy of village funds and a change in pattern that was initially centralized into decentralization, of course, became a new challenge for village apparatus and village community. Some of the objectives contained in Act No. 6 of 2014 Article 4 include increasing public services to realize public welfare, creating a village that can maintain social unity, improving the economy of the village community.

\footnotetext{
${ }^{1}$ Student of Master of Law, Sultan Agung Islamic University (UNISSULA), Semarang, email: ahmadridwan123@gmail.com

${ }^{2}$ Lecturer of Faculty of Law, Sultan Agung Islamic University (UNISSULA), Semarang
} 
Regarding village development with changes in community structure, the village has the authority to regulate and take care of community interests according to its own initiatives based on the socio-cultural community, meaning that it provides opportunities for the growth and development of social institutions according to social and cultural needs and conditions with this understanding, so position of villages that have autonomy is very strategic so it requires balanced attention to the implementation of regional autonomy because with strong village autonomy will significantly affect the realization of regional autonomy.

The village is a socio-political entity that is very important and has unique characteristics in the formal institutional structure of the government of the Unitary Republic of Indonesia (NKRI). The village is also a leading entity in all processes of nation building and the Indonesian State. This is because the existence of villages that existed long before the State of Indonesia was established. The new law, namely Act No.8 Of 2016 Regarding the Second Amendment to Government Regulation Number 60 Of 2014 Regarding Village Funds Sourced from the State Budget, namely that in the context of implementing the distribution, reporting, and monitoring and evaluation of Village Funds sourced from State budget, ${ }^{3}$

Since the enactment of Act No. 6 of 2014 on Villages, the government, the provincial regional government, and the regency / city regional government can arrange village arrangements. The arrangement as referred to in Article 1 of Act No. 6 of 2014 on Villages is based on the results of evaluations of the level of development of village governance in accordance with the provisions of the Statutory Regulations. It aims to realize the effectiveness of the administration of village governance, accelerate the improvement of the welfare of the village community, accelerate the improvement of the quality of public services, improve the quality of governance of the Village Government, and improve the competitiveness of the Village (Act No. 6 of 2014 on Villages Article 7Ayat 3).

This research was conducted in the Kadiwono Village, Bulu District, Rembang Regency. By using the Village Development Planning Deliberation forum

(Musrembang Desa) as a forum for the gathering of all elements in the community are expected to produce a participatory plan, give rise to a sense of responsibility together, respect each other and supervise each other in a spirit of togetherness for a greater interest that is building a village to improve the welfare of the community more independent and actively participate in village development.

Based on the background described above, it can be formulated the problems in this study, namely: How is the implementation of village funds in the form of development in Kadiwono Village, Bulu District, Rembang Regency?

\section{Research methods}

To conduct a study in this study the writer uses the sociological juridical method to study and discuss the problems raised. Juridical is an approach that uses legal

\footnotetext{
${ }^{3}$ Ahmad Mustanir, Darmiah, 2016, Implemntasi Kebijakan Dana Desa dan Partisipasi Masyarakat Dalam Pembangunan di Desa Teteaji Kecamatan Tellu Limpoe Kabupaten Sidenreng Rappang, Jurnal Politik Profetik, STISIP Muhamadiyah Rappang, Vol 04 No.2, p.227.
} 
principles and principles derived from written regulations ${ }^{4}$ which regulations governing village development and management of village funds. Whereas sociology is an approach that aims to clarify the real conditions that exist and arise in the community on the problem under study or give importance to the observation steps which look at the practice of implementing village funds in the development of community welfare in the Kadiwono village. ${ }^{5}$

This study uses descriptive research specifications analysis or the nature of the research object exposure. The data used for this study are primary and secondary data. To obtain data in this study, data collection methods such as field observations, interviews, and literature study were used. This research uses descriptive qualitative research analysis method.

\section{Results and Discussion}

\subsection{Implementation of Village Funds in the Form of Implementation of Development in Kadiwono Village, Bulu District, Rembang Regency}

According to Syamsi Yuswar Zainul Basri and Mulyadi Subri, development is a process of system change that is planned towards improvements oriented towards modernist development and social and economic progress. The concept of development is the key to opening a new understanding of the nature of administrative functions in each country and the dynamic nature. Development will run smoothly, if accompanied by good administration. ${ }^{6}$ Development is a process of renewal that is continuous and continuous from a certain situation to a situation that is considered better. development is a series of efforts to realize growth and change in a planned and conscious manner, which is taken by a country towards modernity in the context of fostering the nation. ${ }^{7}$

Village Development is an effort to improve the quality of life and life for the maximum welfare of the village community. ${ }^{8}$ Village development is inseparable from the context of regional development management both at the district and provincial level because the position of the village in a broader context (social, economic, market access, and politics) must look at the inter-village, village within sub-district, inter-district and district and inter-district levels. ${ }^{9}$

Kadiwono Village is a village located in Bulu district, Rembang regency, Central Java. The term Kadiwono Village where Kadiwono comes from the term "Kadewan" which means "God" in Hindu-Buddhist beliefs. Kadiwono Village lies between two mountains to the north of the Soldiers Mountains and to the south of the Bolodewo

\footnotetext{
${ }^{4}$ Zainudin Ali, 2009, Metode Penelitian Hukum, Sinar Grafika, Jakarta, p.98.

${ }^{5}$ Rony Hanitijo Soemitro, 1990, Metodologi Penelitian Hukum dan Jurimetri, Ghalia Indonesia, Jakarta, p.34

${ }^{6}$ Syamsi Yuswar Zainul Basri \& Mulyadi Subri, 2006, Keuangan Negara dan Analisis Kebijakan Publik, PT Raja Grafindo Persada, p.15

7 Sondang P. Siagian, 2001, Manajemen Sumber Daya Manusia, Bumi Aksara, Jakarta, p.6

${ }^{8}$ Article 1 Paragraph (9) Regulation of the Minister of Villages, Development of Disadvantaged Regions, and Transmigration Number 3 of 2015 on Village Assistance

${ }^{9}$ Wahjudin, in Nurman, 2015, Strategi Pembangunan Daerah, 1st Printing, PT. Raja Grafindo Persada, Jakarta, p.266-267
} 
Mountains. ${ }^{10}$ Like other villages, Kadiwono Village also received village funds with a sizable allocation. In 2019 Kadiwono's APBDes income was Rp. 1,500,432,113. The income is used for spending on village development activities by $52 \%$; village government administration activities by $33 \%$; community empowerment activities amounting to Rp. $12 \%$, and the remaining 3\% for community development activities. Although there is SILPA (Remaining Over Previous Year Budget Calculations) in 2018, the amount is less than $30 \% .{ }^{11}$

Kadiwono village itself has realized the importance of infrastructure development for the community, where there are still many obstacles faced by farmers in the village, especially in the planting process and the village harvest process. This is clearly seen where there are still many access roads that cannot be traversed by crops transporting cars, of course this is very influential in the process of distributing agricultural products. With the allocation of village funds, which where the funds came with a foundation to build villages by the central government, it was clear that the Munte village began to utilize the village funds that were brought in. Much of the infrastructure development that has been carried out by the Kadiwono village from 2013 to the present has taken advantage of the allocation of village funds, especially access to agricultural roads that are needed by the Kadiwono community. ${ }^{12}$

The infrastructure development of Kadiwono Village does not stop at the access road of agriculture and irrigation networks, which is the potential of the Kadiwono community in developing the economy because the majority of the people of Kadiwono are farmers. In 2019 the development of village infrastructure refers to the development of Kadiwono village road access, such as the construction of Kadiwono village school roads, the construction of the Kadiwono village communication network, and village drainage and also the scope of infrastructure in the village administration. Can be seen in the table of realization of the implementation of the village revenue and expenditure budget in 2019 below:

\section{Income}

\begin{tabular}{|c|c|c|}
\hline No & Source of Income & Nominal \\
\hline 1 & Village Fund & IDR $783,183,000$ \\
\hline 2 & Tax Revenue Share & IDR $28,302,700$ \\
\hline 3 & Profit Sharing Profit & IDR $7,070,300$ \\
\hline 4 & Allocation of village funds & IDR $247,094,000$ \\
\hline 5 & Provincial Financial Aid & IDR $355,000,000$ \\
\hline 6 & District Financial Aid & IDR $70,000,000$ \\
\hline 7 & Remaining Budget for 2018 (SILPA) & $\mathrm{Rp} 9,782,113$ \\
\hline
\end{tabular}

Source: APBDes for Fiscal Of 2019, Kadiwono Village, Bulu District, Rembang Regency

\footnotetext{
${ }^{10}$ Interview with Pratikno, Community Leader in Kadiwono Village, Rembang Regency, on 3 February 2019

${ }^{11}$ Interview with YPP Speaker, Secretary of Kadiwono Village, Rembang Regency, on 15 February 2020

${ }^{12}$ Interview with YPP Speaker, Secretary of Kadiwono Village, Rembang Regency, on 15 February 2020
} 


\section{Village Shopping}

Field Administration of Village Government

\begin{tabular}{clr}
\hline No & \multicolumn{1}{c}{ Shopping } & \multicolumn{1}{c}{ Nominal } \\
\hline 1 & Siltap Village Head \& Village Apparatus & IDR $100,800,000$ \\
\hline 2 & Village Heads \& Village Allowances & IDR $39,600,000$ \\
\hline 3 & BPJS Health Village Head \& Village Apparatus & IDR $4,212,000$ \\
\hline 4 & BPJS of Employment & IDR 714,000 \\
\hline 5 & Allowances for Chairpersons \& Members of the BPD & Rp, 200,000 \\
\hline 6 & BPD Operations & IDR $8.100,000$ \\
\hline 7 & RT / RW Operations & IDR $13,500,000$ \\
\hline 8 & BPD Operational Vehicles & IDR $15,000,000$ \\
\hline 9 & Village Archive Cupboards 1 Fruit & Rp $10,000,000$ \\
\hline 10 & Chitose Office Chair 15 Pieces & IDR $5,250,000$ \\
\hline 11 & Epson Office Village Offices & IDR $2,500,000$ \\
\hline 12 & Photocopy & IDR $2,520,000$ \\
\hline 13 & Additional Village Head Income \& Village Devices & Rp $12,600,000$ \\
\hline 14 & Administration fee & IDR 6,600,000 \\
\hline 15 & ATK (BHPD \& BHRD) & IDR $16,173,000$ \\
\hline & & IDR 256,769,400 \\
\hline Source: APBDes for Fiscal Of 2019, Kadiwono Village, Bulu District, Rembang Regency
\end{tabular}

Source: APBDes for Fiscal Of 2019, Kadiwono Village, Bulu District, Rembang Regency

Development Sector

\begin{tabular}{clr}
\hline No & \multicolumn{1}{c}{ Shopping } & \multicolumn{1}{c}{ Nominal } \\
\hline 1 & Continuation of Asphalting Road RT 07 & Rp. $118,687,000$ \\
\hline 2 & Hardening the Road & Rp. $22,240,000$ \\
\hline 3 & Channel Normalization / Drainage & Rp, 580,000 \\
\hline 4 & Construction of Road Shoulder Concrete \& Channel Cover Plate & Rp. $19,287,000$ \\
\hline 5 & Concrete Rabat Road Construction \& Renovation & IDR $45,714,000$ \\
\hline 6 & River Parapet / Cliff Development & IDR $11,707,000$ \\
\hline 7 & Construction of Street Lights \& Plangization & Rp $111,013,000$ \\
\hline 8 & RTLH (10 Houses) & Rp $100,000,000$ \\
\hline 9 & Village Library Operations & IDR $20,000,000$ \\
\hline 10 & Posyandu Activity Facility & IDR 40,000,000 \\
\hline 11 & Youth Posyandu Operations & IDR 4,910,000 \\
\hline 12 & Village Self-Awareness \& Village Consensus Survey & IDR $11,000,000$ \\
\hline 13 & Photographer Training & IDR $20,000,000$ \\
\hline 14 & Capacity Building for Village Tourism Managers & IDR 30,000,000 \\
\hline 15 & Development of Tourist Area Fence & IDR $70,000,000$ \\
\hline 16 & KPMD Operations & Rp 5,000,000 \\
\hline 17 & PMT & IDR 20,000,000 \\
\hline 18 & RTLH (3 houses) BankeuProv & IDR 30,000,000 \\
\hline 19 & Development of Cultural Studio & IDR 150,000,000 \\
\hline & & IDR 949,138,000 \\
\hline & &
\end{tabular}


Source: APBDes for Fiscal Of 2019, Kadiwono Village, Bulu District, Rembang Regency

Division of Community Development

\begin{tabular}{clr}
\hline No & \multicolumn{1}{c}{ Shopping } & Nominal \\
\hline 1 & PKK Operations & Rp. $4,400,000$ \\
\hline 2 & LPMD Operations & IDR $8.100,000$ \\
\hline 3 & Karangtaruna Operations & IDR 4,098,800 \\
\hline 4 & Operational Linmas & IDR 4,098,800 \\
\hline 5 & Village Well Community Capacity Training & IDR $8,150,000$ \\
\hline 6 & Village Institution Capacity Building Training & IDR $8,600,000$ \\
\hline & & IDR 42,447,600 \\
\hline
\end{tabular}

Source: APBDes for Fiscal Of 2019, Kadiwono Village, Bulu District, Rembang Regency

Field of Community Empowerment

\begin{tabular}{clr}
\hline No & \multicolumn{1}{c}{ Shopping } & \multicolumn{1}{c}{ Nominal } \\
\hline 1 & Technical Cadre Capacity Building Training (Joint) & IDR $1,348,250$ \\
\hline 2 & Strengthening Admin Training Ready to Village (Together) & IDR $2,703,250$ \\
\hline 3 & Tax Socialization (Together) & Rp 642,750 \\
\hline 4 & Legal Product Training (Together) & IDR 728,750 \\
\hline 5 & SID Admin Strengthening Training (Together) & Rp. 3,118,450 \\
\hline 6 & KPMD Capacity Building Training & IDR 438,750 \\
\hline 7 & Equity Participation in Joint Bumdes & IDR 50,000,000 \\
\hline 8 & SLRT management & Rp 5,000,000 \\
\hline 9 & Capacity Building for Bumdes Management & IDR $7,567,650$ \\
\hline 10 & Village Deliberation & IDR $17,000,000$ \\
\hline 11 & Siskeudes Admin Strengthening Training (Together) & Rp 3,747,150 \\
\hline & & IDR $92,295,000$ \\
\hline
\end{tabular}

Source: APBDes for Fiscal Of 2019, Kadiwono Village, Bulu District, Rembang Regency

From the description of the table, in 2019 Kadiwono Village divides 4 fields in village expenditure through the allocation of village funds, namely the field of village administration to fulfill the internal needs of the village administration, the development sector as village expenditure to carry out village infrastructure development, the field of community development to manage labor increases human resources in the village and their supporters, as well as the field of community empowerment as a form of village community participation in participating participate in managing and building the village.

As a community leader, Pratikno also added that the Kadiwono villagers also felt the direct impact of the development of village infrastructure, especially with the construction of a central agricultural road. The Kadiwono community was greatly helped after the agricultural central road had been built with concrete rebates, of course it was very felt because the road was still difficult to access by harvesting vehicles especially when the rain became muddy so the vehicle could not pick up the crops of the farming community in Kadiwono Village, so in the past it still used buffalo 
cart transportation to deliver the crops of the Kadiwono village peasants to the storage shed for grinding, ${ }^{13}$

A policy is clearly seen when it has an implementor or an institution that implements it well. In carrying out a policy or program it must be supported by the implementation of competent and capable policies for the success of a policy and this must already be exposed or recorded properly. Whether a policy has specified the implementor in detail. The village fund implementer is the village government and all the people in Kadiwono village, so in the process of implementing a policy we involve all Kadiwono people to express their opinions in the musrembangdes with the aim of developing villages with our own village needs and the community is directly involved in the process. $^{14}$

\section{Closing}

\subsection{Conclusions}

In 2019, Kadiwono Village, Bulu District, Rembang Regency received a Village Income of Rp 1,500,432,113 consisting of village funds, tax revenue sharing, revenue sharing fees, village fund allocations, provincial financial assistance, district financial assistance, and the remaining 2018 budget (SILPA). In the village expenditure, Kadiwono Village divides 4 sectors in village expenditure through the allocation of village funds, namely (1) the field of village administration as meeting internal village government needs with a nominal Rp 256,769,400, (2) the development sector as village expenditure to carry out village infrastructure development with a nominal value of $\mathrm{Rp}$. $949,138,000$ (3) in the area of community development to manage the increase in the number of human resources in the village and its supporters with a nominal value of Rp.44,447,600.

\subsection{Suggestions}

- With the existence of the village fund allocation fund, it is certainly expected that development in the village will be better and able to prosper the village community by utilizing the allocation funds optimally and wisely;

- The government needs to provide assistance and assistance on increasing the capacity of village financial management, governance management to the village apparatus. Village facilitation or facilitation activities, participatory training for the community, apprenticeships, comparative studies, advocacy and so on must be a permanent program of the government to improve the collective capacity of village officials by involving various parties; Non-governmental organizations, community groups, private universities and so on.

\section{REFERENCES}

\footnotetext{
${ }^{13}$ Interview with Pratikno, Community Leader in Kadiwono Village, Rembang Regency, on 3 February 2019

${ }^{14}$ Interview with YPP Speaker, Secretary of Kadiwono Village, Rembang Regency, on 15 February 2020
} 


\section{Book}

[1] Khudzaifah Dimyati and Kelik Wardiono, 2004, Metode Penelitian Hukum, Universitas Muhammadiyah Surakarta, Surakarta.

[2] Rony Hanitijo Soemitro, 1990, Metodologi Penelitian Hukum dan Jurimetri, Ghalia Indonesia, Jakarta.

[3] Sondang P. Siagian, 2001, Manajemen Sumber Daya Manusia, Bumi Aksara, Jakarta.

[4] Syamsi Yuswar Zainul Basri \& Mulyadi Subri, 2006, Keuangan Negara dan Analisis, Public Policy, PT Raja Grafindo Persada.

[5] Wahjudin, in Nurman, 2015, Strategi Pembangunan Daerah, 1st Printing, PT. Raja Grafindo Persada, Jakarta.

[6] Zainudin Ali, 2009, Metode Penelitian Hukum, Sinar Grafika, Jakarta.

\section{Statutory Regulations}

[1] The 1945 Constitution of the Republic of Indonesia

[2] Act No. 6 of 2014 on Villages

[3] Act No.8 of 2016 on the Second Amendment to Government Regulation Number 60 of 2014 on Village Funds Sourced from the State Expenditure Budget

[4] Regulation of the Minister of Villages, Development of Disadvantaged Areas, and Transmigration Number 3 of 2015 on Village Assistance

\section{Journal}

[1] Ahmad Mustanir, Darmiah, Implementasi Kebijakan Dana Desa dan Partisipasi Masyarakat Dalam Pembangunan di Desa Teteaji Kecamatan Tellu Limpoe Kabupaten Sidenreng Rappang, Prophetic Political Journal, STISIP Muhamadiyah Rappang, Vol 04 No.2, 2016 